THE MAREVA INJUNCTION

\title{
AS A MEANS OF AFFORDING PROTECTION TO THE INTERESTS OF CREDITORS
}

By

Dr. Mohammed Saud Alnasair

\begin{abstract}
Alenaze *
Abstract :
\end{abstract}

The English Legal system of the earlier days had sought to build a very efficient system of remedial justice for the people in regard to various matters, civil and criminal, but one of the segments of the system, namely, the Common Law in course of time had become so rigid and so technical in certain respects that a deficiency had crept into the system of granting remedies in regard to certain situations. Because of the rigidity of principles and the technicalities of procedures the law was not in a position to help the persons in difficulty. The principles of Equity rose to the occasion and came to the rescue of such helpless creditors. So much so that the English court met the challenges of the time through its innovative mechanism of remedies like the Mareva Injunction and the Anton Pillar Orders and afforded protection in its own way to the creditors. Thus, the remedy of Mareva Injunction having its basis in the Principles of Equity was one of 
the most significant contributions of the English Law to the system of remedies.

This particular remedy initially was in the sphere of Commercial Law to protect the interests of the creditors who on account of the dubious conduct of the debtors were not able to get due protection to interest, but the courts later on extended the scope of the remedy to other areas too. The territorial extent of the remedy also was extended to properties of the defendants located beyond the jurisdiction of the court where the action for Mareva injunction was instituted. contributed to the resurgence of the system of remedial justice in the universe of Commercial Law in general and the world of Remedial Justice in particular.

Key Concepts :

The Common Law Remedies in Commercial Transactions;

Remedies based on Principles of Equity;

Mareva Injunction, and Anton Pillar Orders;

Extension of Mareva Injunction to various other matters. 
Head, Department of

Private Law, Faculty of Law, University of Bahrain, The Kingdom of Bahrain.

This article has the object of discussing, in the beginning, the nature and scope of the Common Law and Equitable Remedies in commercial transactions and then tracing the emergence of Mareva Injunction as an instrument of justice in the realm of Commercial transactions. Proceeding further on the subject the author highlights the principles relating to the remedy of Mareva injunction and the principles which are followed by the courts in the matter of granting the remedy of Mareva Injunction and then the discussion covers the practice followed in certain foreign jurisdictions with regard to the remedy of Mareva Injunction.

\section{The Nature and Scope of Common Law Remedies in Commercial Transactions:}


The principal elements of English Law are: the Common Law, Principles of Equity and the Statute. ${ }^{1}$ The Common Law was the first source of English Law but then Equity played a dynamic role. Penny Darbyshire writes: “ ... in England, at no time was it felt necessary to look outside the principles of common law or equity for assistance Inevitably, through the ecclesiastical courts in particular, some Roman Law influence can be traced but in general terms this is very limited. ${ }^{2}$

Coming to the basic features of English Law, it may be said that the system of remedies in English Law of the earlier days was based upon the Principles of Common Law which also contained the theories of jurisdiction. ${ }^{3}$ The first thing that needs to be pointed out about these matters is that the procedure of the Common Law Courts was devised in the Forms of Action which were mostly in the form of Writs. ${ }^{4}$ The earliest form of Writ was the Writ of Trespass'. An aggrieved person, if he wanted to maintain an action in the Royal Courts he had to obtain a writ from the office of the Exchequer and file his action by mentioning the facts of the case. If the action filed by him in the Court succeeded, the resulting relief granted by the court was the Remedy of Damages. Such a procedure was relevant to all

\footnotetext{
${ }^{1}$ Collins English Dictionary.

${ }^{2}$ Penny Darbyshire on the English Legal system (2017)

${ }^{3}$ Slapper \& Kelly, 'English Legal System', Rutledge, 2016

${ }^{4}$ Definition of Common Law in Oxford English Dictionary (1933)
} 
forms of action whether they were related to Torts, family problems, property or commercial relations. In such a system of remedies more importance was given to the availability of form of action, which meant that the substantive relief depended upon the availability of the procedural form of action. ${ }^{5}$ Such a state of affairs was characterised by the statement: 'Ubi Remedium, Ibi Jus' which meant that if there was a remedy (a form of action) available in regard to a certain matter there could be recognition to the right of a person and protection was afforded to the interests of the person by way of the enforcing his right in the court of law. In other words, the procedural law was more important than the substantive law, which had prescribed the right of a person. In the realm of Common Law the system of writs had become so popular that the remedy of damages had earned the name of Golden Remedy of Damages.

Thus, the legal system under the Common Law was based on Writs and if a Writ was not available on a subject, the courts could not provide a remedy to the aggrieved person. But because of certain rigidities in matters of procedure the Common Law had become deficient in the matter of granting the remedy of damages. Particularly in the sphere of commercial transactions it had a limited scope of relief. For example, if the debtor avoided the obligation of paying off the debt and ran away from the place

\footnotetext{
${ }^{5}$ Pollock and Maitland, History of English Law.
} 
where the transaction was executed or if he removed his properties to a place where it could not be reached by the court to satisfy the claim of the creditor the Common Law could afford no protection to the creditor. ${ }^{6}$

Aggrieved by such a situation, people took their cases to the King who was the fountain of all justice, and they requested him for relief from the Royal authority. The King delegated the decision making of the Chancery who used to be an ecclesiastic, who on behalf of the King exercised the judicial powers and provided relief to the aggrieved persons. Thus came into existence the Court of Chancery and the principles which the ecclesiastics evolved, namely, the principles of justice, morals, and good conscience, came to be known as the Principles of Equity. ${ }^{7}$ These principles guided the Chancery in moulding the institution of Justice and provided new remedies where none existed at Common Law.

As an alternative procedure, the responsibility of doing justice was assumed by Equity. In the new regime that came up the principles of justice could be characterised as "Ubi Jus Ibi Remedium" which meant that if there was a right recognized by law in a certain transaction, the Court will provide a remedy for its

\footnotetext{
${ }^{6}$ History of English Law before the Time of Edward I, 2 vols. S. F. C. Milsom, Cambridge University Press,1968

${ }^{7}$ Snell, Edmund Henry Turner, Megarry, R. E., Baker, P.V. (1960) 'Snell's Principles of Equity, $25^{\text {th }}$ Edition, London, Sweet \& Maxwell, p. 10
} 
enforcement of that right. A simple version of this rule was "where there is a right, there ought to be a remedy".

A more serious implication of this maxim was that the concept of justice in society was no longer to be the exclusive right of the Common Law. The monopoly hitherto enjoyed by the Common Law was broken by the second source of English Law, namely, the Principles of Equity which formulated its own principles to do justice to the aggrieved person. By virtue of the liberal approach adopted by the Courts on the basis of the principles of Equity the state of affairs was rightly characterised by the new maxim: "Ubi Jus, Ibi Remedium”.

\section{The nature and scope of Equitable Remedies}

\section{In commercial transactions}

Thus, a second source of English Law played a very important role in the matter of providing remedies to the aggrieved persons. In several peculiar situations, Equity rose to the occasion, and provided new remedies, recognized new rights and modified the existing unfavourable procedures. The particular remedies that were provided by Equity through its new methods 
were the remedies of Specific Performance, Injunction, Restitution, Declaration, appointment of Receiver etc.

A principle of far reaching significance which Equity introduced in the matter of establishing the jurisdiction of the Court was the principle of Jurisdiction in personam. The fundamental principle on which the remedy of Injunction is based is the jurisdiction in personam. By exercising such a jurisdiction the Court of Equity could order the transfer of assets of a person from one jurisdiction to another. In Derby v. Weldon (No.6) ${ }^{8}$ it was held that the English courts even have a power to order the defendant to transfer his assets from one jurisdiction to another. The Court of Appeal's reasoning was that the "in personam jurisdiction of the English court is 'unlimited. Dillon LJ stated that the jurisdiction extended to :

"ordering the transfer of assets to a jurisdiction in which the order of the English court after the trial of the action will be recognized, form a jurisdiction in which that order will not be recognised and the issues would have to be re-litigated, if ... the only connection of the latter jurisdiction with the matters in issue in the proceedings is that moneys have been placed in that jurisdiction in order to make them proof against the enforcement, without full retrial in a foreign court, of

${ }^{8}$ (1990)1 WLR 1139 
any judgment which may be granted to t he plaintiffs by the English court in this action or indeed if the only connection with the latter jurisdiction is financial, as a matter of controlling investments."

The contribution of Equity to the system of remedial justice has been highlighted in many of the treatises of eminent jurists like Snell ${ }^{9}$, Hanbury and Maudsley ${ }^{10}$, Joseph Story ${ }^{11}$, Barnard and Houghton. ${ }^{12}$ Snell in his 'Principles of Equity', for example, says,

"As has confounded first year law students for centuries, the power of a court to pursue justice between the parties does not simply reside in its legal authority; Rather, a court also has an equitable authority which, in some cases, extends further than its legal mandate."

Spry, while discussing the bases of the Marvea injunction jurisdiction, has commented that it is certainly with the inherent jurisdiction of the courts of equity to grant Marva injunctions. ${ }^{\text {,13 }}$

9 "Principles of Equity", P. V. Baker and T. St. J. Langan, ed. $28^{\text {th }}$ Ed 1909

10 "Modern Equity" 784 (Jill E. Martin, $12^{\text {th }}$ Ed., 1985

11 "Commentaries on Equity Jurisprudence", $11^{\text {th }}$ Ed., 1873

12 "New Civil Court in Action". 247. (1948).

${ }^{13}$ Spy 'The Principles of Equitable Remedies ( ${ }^{\text {th }}$ ed., 1997) 515 
In the famous case: Nippon Yusen Kaisha . Karageorgia ${ }^{14}$, Lord Denning, the most eminent Judge of the Court of Appeal by his ingenuity created an injunction order which was followed in several subsequent cases including the case: Mareva Compania Naviera v. International Bulkcarriers S.A. ${ }^{15}$ in which it was said, if it appears that the debt is due and there is danger that the debtor may dispose of his assets so as to defeat it before judgment, the court has jurisdiction in proper case to grant interlocutory

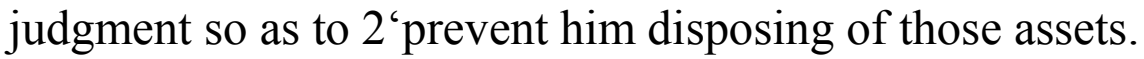

The major principles which guided the learned Judge in formulating the new remedy of Mareva Injunction were the principles of Equity and for that reason the remedy is known as an Equitable Remedy. The Parliament has by its legislation prescribed the remedy as a remedy which could be enforced by the English courts as a legal or equitable remedy. With the passage of time the remedy expanded in its nature and scope from the jurisdiction of the court within the country to areas outside the country and it was known as a remedy of worldwide jurisdiction. Of course, courts of certain foreign countries did have a problem whether to adopt this remedy and enforce the same in their respective jurisdictions. Though the English court had initially called it an Injunction there was criticism as to its

\footnotetext{
${ }^{14}$ (1975) 1 W.L.R. 1093, 1093 (Eng. C.A.)

${ }^{15}$ (1980) 1 ALL ER 213,
} 
name and the discussion centred round the question whether it could rightly be called an injunction.

\section{Background to the Equitable Concept of Mareva}

\section{Injunction}

Prior to 1975, the procedure obtaining in the courts of Common Law for affording protection to the creditors in commercial transactions was to allow an appropriate legal action by the creditor against the debtor if there was a dispute about a certain sum of money to be recovered from him. In case the process did not succeed in the matter of helping the creditor from recovering the debt then the creditor had to proceed against the assets of the debtor by yet another action and obtain a remedy from the court. This process was such that the debtor could frustrate even this legal action of the creditor by removing the assets from the jurisdiction of the court to a place beyond the reach of the court.

Such was the law in England that justice to the creditor depended upon what the law had provided, but then justice was not the monopoly of Common law, there was yet another method by which protection could be afforded to the interests of the creditors, and this was through the second important source of English Legal System, namely, Equity. The principles of equity had the capacity to overpower the law and this it did in a number 
of situations. Among the several methods by which Equity afforded protection to the helpless and needy persons, was by exercising its remedial power in its personam jurisdiction and bind the debtor in his conscience to perform the obligation as undertaken by him or else to suffer in contempt of the Equity jurisdiction. Among the specific remedies that have been afforded to the needy and the disappointed persons in recent years are the Equitable Remedies of Specific Mareva Injunction and Anton Pillar Orders.

Inspired by the dynamic philosophy of Equity, Lord Denning of the Court of Appeal, introduced in the realm of English Law in the year 1975 the remedy of Mareva Injunction which became a popular device in the annals of English Law to afford protection to the interests of the Creditors in the realm of commercial transactions.

\section{Origin of Mareva Injunction :}

Mareva Injunction is a new addition to the Legal Remedies which had existed in the English Legal System under the rules of Common Law. The remedy that had existed earlier in regard to several transactions was the remedy of damages. Until the 1975 decision of the English Court of Appeal victims of fraud had to depend on the remedy that sought to undo the resulting damage. 
Prior to the Supreme Court of Judicature Acts 1873 ad 1875 it was only the Court of Chancery which had the power to grant injunctions. The only remedy available in the common law courts was damages. Section 79 of the Common Law Procedure act 1854 had empowered the courts of common law to grant injunctions in particular cases but this statutory jurisdiction was significantly more limited. It could only be employed where there was an existing power to award damages. The Court of Chancery could grant an injunction based on the fear that an equitable or legal right would be infringed.

The scope of Section 25 (8) of the 1873 Act was considered in Beddow v. Beddow ${ }^{16}$, a case where an injunction was sought to restrain an arbitrator from acting in a case in which allegedly he was unfit or incompetent to act. Jessel M.R. first explained that the jurisdiction given to the Common Law courts by Sections 79, 81 and 82 of the Common Law Procedure Act 1854 was extensive. The only limit was that it must be "reasonable and just" to grant the injunction. The Court of Chancery was not limited by any other terms.

In a number of cases, the most prominent of which was Lister v. Stubbs ${ }^{17}$ it was established that the court of common law cannot grant an injunction "to restrain a man who is alleged to be

\footnotetext{
${ }^{16}$ (1878) 9 Ch. D. 89

${ }^{17}$ (1890) 45 Ch. D. 1
} 
a debtor from parting with or dealing with his property as he pleases." $" 18$.

Another case which raised serious concerns in the area of remedial justice was the case of Lister v. Stubbs. The facts of the case and the principle of law in Lister \& Co. V. Stubbs (1890) may be analysed as follows :

This case concerned a claim by a manufacturing company against its employee to recover the commission which he received from a third party supplier without the knowledge of the company. Part of the secret profit made by the defendant was invested in land. The company claimed to be entitled to follow the money ito those investments. It sought an injunction to restrain the defendant from dealig with the investments or for an order directing him to bring the monies and the invents into the court. The Court of Appeal held that the money received by the defendant could not be treated as being the money of the claimants. As the claimants were not entitled to follow the money into the investments, the injunction was refused.

The court refused to grant the injunction because the money was not that of the plaintiffs so as to make the defendant a trustee, but was money to which the plaintiffs would be entitled to claim in the action, i.e. 'a debt due from the Defendant to the Plaintiffs

${ }^{18}$ Kerr on Injunctions (London: Sweet * Maxwell, $6^{\text {th }}$ edn. 1927, p. 613 
in consequence of the corrupt bargain which he entered into' but

(a) the money which he had received under that bargain could not be treated as being money of the Plaintiffs 'before any judgment or decree in the action had been made' The court will not grant an injunction to restrain a defendant from parting with his assets so that they may be preserved in case the plaintiff's claim succeeds. A claim relating to the acceptance of bribes was not within a proprietary claim.

In line with the case of Lister v. Stubbs were a few more cases which showed that the Common Law remedy of Damages was not sufficient for the purpose and that the remedy of Injunction was unattainable. In Mills v. Northern Railway of Buenos Ayres Co. ${ }^{19}$ the claimants were the unsecured creditors of a company and sought a quia timet injunction to restrain the company from carrying out proposed transactions including the creation of a floating charge and the distribution of dividends to shareholders. The Court of Appeal discharged the injunction granted by the Vice Chancellor, Lord Hatherley LC who asserted that "the only remedy for a creditor in that case is to obtain his judgment and to take an execution." 20 The creditor could not by

${ }_{20}^{19}(1869-70)$ L.R. 5 Ch. App. 621

${ }^{20} \mathrm{Ibid}, 628$ 
means of a quia timet injunction, obtain security for the payment which he expects to receive in the future. ${ }^{21}$

The same approach was also taken in a number of matrimonial cases. In Robinson v. Pickering ${ }^{22}$ a creditor wanted to enforce the alleged debt against the separate estate of a married woman. The Court of Appeal held that until the creditor had obtained judgment and thereby established his right, he could not restrain the married woman from dealing her separate estate.

In commercial relations parties were free to do what they liked with their own assets prior to judgment. After judgment, a judgment creditor's nly remedy was to take out execution. ${ }^{23}$ But a change occurred in the year 1975 and that was a change of far reaching significance. The change was such that the Court of Appeal set off the greatest piece of judicial activism. The Court assed an ex parte interim freezing order - or freezing injunction restraining the removal of assets from the jurisdiction. This happened in the case known as Nippon Yusen Kaisha V. Karageorgis $^{24}$ the plaintiff company had chartered a ship to the defendants. A large sum was now claimed for hire, and a string prima facie case made out. The charterers could not be found but there was evidence of funds at a bank in London. An ex parte

\footnotetext{
${ }^{21} 628$

${ }^{22}(1880-81)$ L.R. 16 Ch. D. 660

${ }^{23}$ Lister \& Company v. Stubbs (1890) 46 Ch 1

${ }^{24}$ CA 1975 WLR 1093
} 
application to grant an injunction restraining the charterers from disposing of or removing from the jurisdiction any of the assets which were within the jurisdiction was refused. The company preferred an appeal which succeeded. The court 'rediscovered' its ability to make interim asset freezing. By its order the English Court of Appeal held that a plaintiff can limit a defendant's ablity to dispose of assets prior to a judgment of the court, which is called a 'Mareva Injunction'.

The reason for the granting of such an injunction was that otherwise the assets were in danger of being removed form the jurisdiction so as to frustrate a money judgment whch the Japanese shipowners had against Greek charterers for the hire of a ship. The charterers had disappeared but had funds in London Banks. The Court of Appeal indicated that the order be notified to the banks.

A month later the Court of Appeal followed the earlier decision when a similar emergency arose in Mareva Compania Naviera SA v. International Bulkcarriers SA (The Mareva) ${ }^{25}$. Again, shipowners were owed money for charter hire and the charterer had money in a London bank. An ex parte interim freezing injunction was made stopping the funds from being taken out of the jurisdiction. Again, notice of the injunction was given to the bank. The early English cases on injunctive relief of this kind

${ }^{25}$ (1975) 2 Lloyd's Rep 509 (1980) 1 All ER 213. 
were based on the principles of Civil Law, where attachment of assets prior to the determination of legal proceedings was well established in jurisdictions such as Germany, Italy and France.

The Court of Appeal which created the Mareva injunction in 1975 in the case of Nippon Yusen Kaisha case touched off the greatest piece of law reform during the life time of Lord Denning. Lord Denning, Master of the Rolls said,

"We are told that an injunction of this kind has never been granted before; It has never been the practice of the English courts to seize assets of a defendant in advance of judgment or to restrain the disposal of them."26

It was time his Lordship decided, to revise such a practice. The Court held:

'There is no reason why the High Court or this court should not make an order such as is asked for here. It is warranted by section 45 of the Supreme Court of Judicature (Consolidation) Act, 1925 which says that the High court may grant a mandamus or injunction or appoint a receiver by interlocutory order in all cases in which it appears to the court to be just or convenient so to do. It seems to me that this is jus such a case. There is a strong prima facie case that the hire is owing and unpaid. If an injunction is not granted,

${ }^{26}$ Nippon Yusen Kaisha v. Karageorgis, (1975)1 W.L.R. 1093, 1094 (CA) 
these moneys may be removed out of the jurisdiction and the shipowners will have the greatest difficulty in recovering anything. Two days ago we granted an injunction ex parte and we should continue it" 27

Barely a month later the Court of Appeal in Mareva Compania Naviera SA .v. International Bulkcarriers SA ${ }^{28}$ again utilized the new procedure and gave it its name.

Both Nippon Yusen and Mareva were ex parte injunctions. In neither case did defendants apply to discharge the injunctions so that only the creditors side was heard. For the authority to be complete both sides needed to be heard. For the authority to be complete, both sides needed to be heard. Such a case finally came up two years later in Rasu Maritima SA v. Purushaaan Pertambangan Minyak Dan Gas Bumi Negara $^{29}$

Plaintiff shipowner sued defendant charterer for damages of nearly 2,000,000 pounds for breach of a charter party. After numerous futile attempts in severl ountries to attach defendant's assets, plaintiff finally found some equipment purportedly belonging to defendant waiting to be shipped form Liverpool. Plaintiff immediately applied ex parte for an

\footnotetext{
27 Nippon Yusen Kaisha v. Arageorgis, (1975) 1 WLR 1093, 1094 (CA)

${ }^{28}$ (1980) 1 All ER 213 (CA)

${ }^{29}$ (1978) 1 QB 644 (CA)
} 
injunction to restrain the shipping of the equipment, and the defendant applied to discharge the order. The Court of Appeal discharged the injunction on two grounds. First, thre was a serious question as to whether defendant held valid title to the equipment. Second, the value of the equipment to defendant (it was to be used as part of a proposed plant) far outweighed its value to plaintiff if seized and sold under execution of judgment. The court would issue an injunction only if it were "just or convenient" to do so .and since it had grave doubts as to the merits of plaintiff's case the court did not continue the injunction.

Two months later, the House of Lords not only reviewed the Mareva injunction but reversed an application of it in Siskina v. Distos Compani Naviera SA. ${ }^{30}$

The High Court granted an injunction, and the Court of Appeal upheld it. The case then went to the House of Lord which reversed on the narrow ground that the Mareva injunction could not be extended to provide a general power of attachment wee the court had no other basis of jurisdiction over defendants oter than plaintiff's application for an interim injunction. In this decision, the House of Lords reviewed the Mareva principle but did not challenge it. Lord Hailsham of Saint Marylebone said, "Since the House is in 
no way casting doubts on the validity of the new practice by its decision in the instant appeal, I do not wish in any way to do so myself...." None of their Lordships did cast any doubt on it. The Mareva injunction has become part of English jurisprudence.

The Mareva procedure has recently been codified as section 37 (1) of the Supreme Court Act, 1981 which contains the following subsection:

"The power of the High Court under subsection (1) to grant an interlocutory injunction restraining a party to any proceedings from removing from the jurisdiction of the High Court, or otherwise dealing with, assets located within that jurisdictions shall be exercisable in cases where that party is, as well as in cases where he is not, domiciled, resident or present within that jurisdiction." 31

\section{The Nature of Mareva Injunction :}

1) Though English Law adopted the system of prejudgment attachment through the remedy of Mareva but it was not an early

\footnotetext{
${ }^{31}$ Supreme Court Act 1981, ch. 54, sec. 37 (1)
} 
development in European countries because countries like France and Scotland already had the system of prejudgment attachment. In France, for example, the process of Saisie conservatoire had existed for many years. The words literally meant a 'conservative seizure' or a 'seizure of assets so as to conserve them for the creditor in case he should afterwards get judgment. ${ }^{32}$ In Scotland, the law or arrestment achieves basically the same purpose. ${ }^{33}$ The English Courts created the Mareva injunction in 1975 to afford some prejudgment protection to creditors.

2) The Mareva injunction does not convert an unsecured creditor into a partially secured creditor by creating proprietary rights in a debtor's assets, nor does it give a creditor priority in insolvency proceedings.

3) The Mareva injunction operates in personam to restrain a debtor from dealing with his or her assets until the court enters judgment.

4) The Mareva injunction is granted in most cases as a form of interlocutory relief.. ${ }^{34}$

5) The scope of Mareva injunction is not limited to commercial debts. The injunction may support a claim for personal injuries. ${ }^{35}$

\footnotetext{
${ }^{32}$ A. Denning, The De Process sof Law, 133 (1980)

${ }^{33}$ R. J. Walker Principles of Scottish Private Law 163-64 (2d ed. 1975)

${ }^{34}$ Supreme Court of Judicature (Consolidation) Act, 1925
} 
6) A very important aspect of Marva Injunction is its discretionary character. The traditional requirement for an equitable remedy is that the common law remedies must be inadequate before recourse can be made to equitable remedies, such as injunctions. This rule has created a remedial hierarchy, with common law remedies, generally damages, eing superior to equitable remedies, which only have a role to play where the legal remedies are inade3uate. By his scholarship Laycock has shown that this rule does not decide cases but only reinforces the court's decision regarding the appropriate remedy. ${ }^{36}$

7) Difference between Mareva Injunctions and Proprietary Injunctions

In a recent case of Zimmer Sweden AB v KPN Hong Kong Ltd and Brand Trading Limited ${ }^{37}$, the Hong Kong High Court upheld two injunctions granted in favour of a company which was the alleged victim of fraud perpetrated in Sweden. In doing so, the Court provided a welcome analysis of the distinction between asset freezing injunctions (commonly known as Mareva injunctions) and proprietary injunctions.

The Plaintiff, Zimmer Sweden AB ("Zimmer"), was the victim of an alleged fraud perpetrated in Sweden, which resulted

\footnotetext{
${ }^{35}$ Allen v. Jambo Holdings Ltd. (1980) 1 WLR 1252

${ }^{36}$ Dobbs, Law of Remedies, $\left(2^{\text {nd }}\right.$ ed., 1993)

37 HCA 2264/2013
} 
in losses of EUR 487,000. Part of these sums were allegedly paid into the bank accounts of KPN Hong Kong Ltd and Brand Trading Limited (the "Defendants"). The Defendants claimed that the monies transferred to their respective accounts were ordinary trade proceeds between two related business entities and not the product or result of fraud.

Zimmer commenced proceedings against the Defendants seeking to recover the money it had lost and obtained separate exparte temporary injunctions against each of the Defendants to prevent them from dealing with monies in their bank accounts (the "Injunctions").

Zimmer then applied to the High Court for continuation of the Injunctions. The Defendants made an application for, amongst other things, discharge of the Injunctions on the ground of material non-disclosure.

On the basis of the evidence, the Court found that there had been no material non-disclosure by Zimmer which would justify discharge of the Injunctions.

The Judge then went on to consider whether the Injunctions should be continued. He held that, although the parties were prepared to argue on the basis that the Injunctions sought were Mareva injunctions, Zimmer was actually asserting a 
proprietary claim to the money in the Defendants' accounts. The Judge cited in particular Falcon Private Bank Ltd v Borry Bernard Edouard Charles Limited, unreported, HCA 1934/2011, to highlight the different applicable tests:

"A Mareva injunction is designed to protect the claimant against the dissipation of assets against which he might otherwise execute judgment whether immediately or in the future... So long as the claimant has a claim against the defendant and that the defendant has assets which may be used to satisfy judgment, a claimant may apply for a Mareva injunction to restrain the defendant from dissipating his assets. A claimant's right to a proprietary injunction is different. It is issued to preserve assets which a claimant has a proprietary claim [sic] so that they can be turned over to the claimant if he is successful in the action. A proprietary injunction is easier to obtain and not subject to the usual liberties inserted into Mareva relief and there is no need to prove risk of dissipation." 


\section{Freezing Injunction or Freezing Order}

For many years this new form of relief was called a Mareva Injunction. Today it is generally called a freezing order in Australia and a freezing injunction in England. These terms now appear in the respective rules of court. Disobedience to a freezing order is punishable as a contempt of court. A third party with notice of the order, such as the respondent's bank is also guilty of contempt if it helps or permits its breach.

In England, the freezing injunction came to be recognized in Section 37 of the Supreme Court Act 1981, which provides :

\section{Powers of High Court with respect to Injunctions}

\section{and Receivers}

(1) The High Court may by order (whether interlocutory or final) grant an injunction or appoint a receiver in all cases in which it appears to the court to be just and convenient to do so.

(2) Any such order may be made either unconditionally or on such terms and conditions as the court thinks just.

(3) The power of the High court under sub-section (1) to grant an interlocutory injunction restraining a party to any proceedings from removing from the jurisdiction of the High Court or otherwise dealing with, assets located within that jurisdiction shall be exercisable in cases where that 
party is, as well as in cases where he is not, domiciled, resident or present within that jurisdiction.

In England, section 25 of the Civil Jurisdiction and Judgments Act., 1982, as extended in 1997, empowers the High Court to grant all forms of freestanding interim relief, including freezing injunctions and search orders, in relation to substantive proceedings anywhere in the world unless, in the opinion of the court, the fact that the court has no jurisdiction apart form this section in relation to the subject matter of the proceedings in question makes it inexpedient for the court to grant it.

The freezing injunction and assets disclosure order is recognized in rule 25 of the Civil Procedure rules 1998 which relevantly provides :

\section{Interim Remedies: Orders for interim remedies :}

(1) The Court may grant the following interim remedies --

(f) an order (referred to as a freezing injunction (GL)

(i) restraining a party from removing from the jurisdiction assets located

there; or 
(ii) restraining a party from dealing with any assets whether located within

the jurisdiction or not;

(g) an order directing a party to provide information about the location of relevant property or assets or to provide information about relevant property or assets which are or may be the subject of an application for a freezing injunction.

\section{Principles relating to the Mareva Injunction}

1) Jurisdiction: The source of the courts' Mareva Injunction is found in section 45 (1) of the Supreme Court of Judicature (Consolidation) Act,1925, which permits the High Court of Justice to grant an injunction " $\mathrm{i}$ all case in which it appears to the court to be just or convenient so to do.. This jurisdictional principle has the meaning that there exists an action, action or potential, claiming substantial relief which the High Court has jurisdiction to grant and to which the interlocutory orders are but ancillary.

2) Balance of Convenience: Section 45 (1) of the Supreme Court of Judicature (Consolidatin) Act, 1925 permits the courts to grant interlocutory injunctions in case where it "just or convenient" to do so. The general principles for interlocutory 
injunctions are set out in the oft-cited American Cyyanamid Co. V. Ethicon Ltd. ${ }^{38}$ Some of these principles are :

First, plaintiff must fully disclose material facts concerning the case.

Second, plaintiff must show that defendant has assets in England. The existence of a bank account is sufficient.

Third, plaintiff must show that there is a risk that defendant would remove his or her assets before the judgment is satisfied.

Fourth, plaintiff ust give an undertaking in case his or her claim fails or if the injunction turns out to be unjustified.

3) Assets Affected The nature of defendant's assets is a major consideration in the court's evaluation of whether it is just or convenient to grant an injunction. The most common asset subject to a Mareva injunction is a bank account. The freezing of such an asset, however may seriously affect a defendant whose commercial survival depend $\mathrm{s}$ on a good cash flow. An undertaking by plaintiff may not always be sufficient indemnity for the loss which defendant might suffer. This has been an area of concern to the courts, and Lord Denning has cautioned against the

381975 AC 396 
granting of an injunction over assets that would bring defendant's business to a standstill. ${ }^{39}$

An analysis of the case law on the equitable principles underlying all types of injunctions demonstrates that the scope of the powers of the Court of Chancery to grant injunctions was extremely wide. As Lord Nicholls explained in Mercedes Benz v. Leiduck $^{40}$

"the jurisdiction to grant an injunction, unfettered by statute, should not be rigidly confined to exclusive categories by judicial decision. The court may grant an injunction against a party properly before it where this is required to avoid injustice, just as the statute provides and just as the court of Chancery did before 1875 . The court habitually grants injunctions in respect of certain types of conduct. But that does not mean that the situations in which injunctions may be granted are now set in stone for all time. The grant of Mareva Injunctions itself gives the lie to this. As circumstances in the world change, so much the situations in which the courts may properly exercise their jurisdiction to grant injunctions. The exercise of the jurisdiction

\footnotetext{
${ }^{39}$ Pertamina, (1978) 1 QB 644,

${ }^{40}$ (1996) AC 284
} 
must be principled, but the criterion is injustice. Injustice is to be viewed and decided in the light of today's conditions and standards, not those of yesterday year."

\section{i) The Siskina case}

- In this case, there was a dispute between cargoowners and ship-owners. The case had no connection with England except that the ship-owners were entitled to insurance moneys which were payable in England. The cargo-owners sought an injunction to restrain the shipowners from dealing with the insurance moneys. However, the ship-owners were a one-ship Panamanian company and there was no substantive claim within the jurisdiction of the court to which the Mareva Injunction sought could be ancillary. The cargo-owners argued that the claim form could be served out of the jurisdiction on the basis of the Rules of the Supreme Court (RSC) Order 11, r. 1. (1)(i).

In a nutshell, the central issue in the Siskina was a narrow legal issue; whether there was an available ground of jurisdiction for service out of the jurisdiction. This was a question relating to the international scope of the

\footnotetext{
${ }^{41}$ Ibid. 308.
} 
freezing injunctions and involved the application of the rules of private international law.

The House of Lords held that the Rules of the Supreme Court Order 11, r. 1 (1) (i) did not allow the assumption of jurisdiction to grant a freezing injunction in relating to the total assets of a person resident outside the jurisdiction in a case which has no other relevant connection with England. In the leading judgment, Lord Diplock took the view that the RSC order 11, 41 ((1 (i) pre-supposed the existence of a cause of action. A claim for an interlocutory injunction was not a cause of action, but was dependent on there being a pre-existing cause of action arising out of an invasion, actual or threatened, of a legal or equitable right of the plaintiff enforceable in England.

Certain exceptions have been carved out to the decision in Siskina. The decision in The Siskina was criticized in a number of significant cases, some of which eroded or modified its scope by creating artificial exceptions to its application. These cases collectively demonstrated that the law of freezing injunctions took a step backwards in the Siskina. It seems that the courts quickly realized that the limits on the power to grant injunctions would hamper the effective enforcement of 
judgments and thereby undermine the needs and expectations of the parties to international commercial litigation. Rigid categorisation of the court's powers to grant freezing injunctions is inconsistent with the fact that the touchstone has always been the demands of justice, providing an opportunity for the courts to cater for new techniques designed to frustrate the enforcement of judgments.

ii) In Mercdes-Benz v. Leiduck ${ }^{42}$ the Privy Council decision sought to lessen the impact of the Siskina. In Leiduck there were substantive proceedings in Monaco against the defendant, a German citizen, for allegedly misappropriating some funds. A Mareva injunction was sought by the claimant in Hong Kong to restrain the defendant from transferring his shares in a Hong Kong company which he controlled. The majority concluded that in a case where the only connection with the forum was the presence of assets within the jurisdiction, the Rules of the Supreme Court did not permit the court to serve the defendant out of the jurisdiction. The majority concluded th in a case where the only connection with the forum was the presence of assets within the jurisdiction, the Rules of the Supreme

4242 (1996) AC 284 
Court did not permit the court to serve the defendant out of the jurisdiction. The majority thereby approved the decision in the Siskina. Lord Nicholls, who gave a dissenting judgment, made reference to quia timet injunctions to show that contrary to Lord Diplock's view in the Siskina, there was no need for a pre-existing cause of action. His Lordship described quia timet injunctions as a classic instance of injunctions granted by the Court of Chancery to prevent anticipated wrongs from being committed.

iii) Rights and duties of third parties : As regards the rights and duties of the third parties in relation to the freezing injunction, rule 6 (5) of the Australian harmonized rules reflects the Australian case law concerning a freezing order against a third party, i.e., a person other than a judgment debtor or prospective judgment debtor:

The Court may make a freezing order or an ancillary order or both against a person other than a judgment debtor or prospective judgment debtor (a third party) if the Court is satisfied, having regard to all the circumstances, that : 
(a) there is a danger that a judgment or prospective judgment will be wholly or partly unsatisfied because:

(i) the third party holds or is using, or has exercised or is exercise, a power of disposition over assets (including claims and expectancies) of the judgment debtor or prospective judgment debtor; or

(ii the third party is in possession of, or in a position of control or influence concerning, assets (including claims and expectancies) of the judgment debtor or prospective judgment debtor or

(b) a process in the Court is or may ultimately be available to the applicant as a result of a judgment or prospective judgment, under which process the third party may be obliged to disgorge assets or contribute toward satisfying the judgment or prospective judgment.

This rule reflects the decision in the leading Australian case on freezing orders against third 
parties, Cardile v. LED Builders Pty. Ltd. ${ }^{43}$ In that case, copyright infringement proceedings in respect of building plans were brought by LED Builders Pty. Ltd. (LED) against Eagle Homes Pty. Ltd. (the old company) which carried on a housing construction business. Judgment was givne for LED. The shares in the old company were held by Mr. And Mrs. Cardile. Months before proceedings were commenced, the old company declared and paid a dividend of $\$ 400,000$ to the shareholders.

LED elected for an account of profits and moved for, first, the joinder of the shareholders and the new company as parties to the action, and secondly, Mareva type orders against the shareholders and the new company pending the taking of the accounts. The primary judge in the Federal Court of Australia dismissed both motions. The Full Federal Court allowed the appeal, holding that Marev relief should have been granted against the shareholders and the new company. They set aside the order dismissing the notice of motion and remitted the matter for determination in accordance with their reasons. The primary judge then promptly made freezing orders

${ }^{43}$ (1999) HCA 18, 198 CLR 380 
restraining the shareholders and the new company from disposing or or dealing any sof their assets other than for specified purposes. On higher appeal by the shareholders and the new company, the High Court unanimously held that there was power to grant Mareva orders against the shareholders and the new company but that the orders should not have extended to all their assets. The guiding principle for determining whether to make a freezing order against a third party was laid down in the joint judgment at (54), (57) and is now reflected in rule 6 (5) of the Australian rules set out above.

\section{The Practice of Mareva Injunctions in foreign Jurisdictions: :}

(i) The practice of Mareva in USA

In several common law jurisdictions the rule followed in commercial law case is one of prejudgment injunction, but when a case came before the US Supreme Court involving the question whether the Courts in United States have jurisdiction to issue such 
an injunction,.the US Supreme Court in Grupo Maxicano de Desarrollo S.A. v. Alliance Bond Fund Inc.

Despite the almost unanimous common-law jurisdiction international support, the U.S. Supreme Court has considered and rejected the application of Mareva orders in the United States. In Grupo Mexicano de Desarrollo S.A. v. Alliance Bond Fund $\underline{\text { Inc. }}{ }^{44}$, the Supreme Court overturned the Second Circuit Court of Appeals and held that federal courts may not issue Mareva injunctions under their inherent equitable powers, citing the "well-established general rule that a judgment establishing the debt was necessary before a court of equity would interfere with the debtor's use of his property." the majority opinion espoused by Judge Scalia in the case was that the courts in United States have no such jurisdiction.to issue an injunction like the Mareva Injunction. U.S. courts have historically looked with disfavor upon the use of prejudgment injunctions that restrain a defendant in a suit from dissipating or transferring assets where the plaintiff simply seeks money damages and claims no interest in specific property belonging to the defendant.

Since Grupo Mexicano, U.S. courts have facially adhered to the ruling of the Supreme Court. $\underline{3}$ Nonetheless, courts and plaintiffs have discovered a means to "plead around" the Grupo Mexicano ruling. Now, if a plaintiff seeking an injunction

$\overline{44} 119$ S. Ct. 1961, 527 US 308 (1999) 
prohibiting a defendant from dissipating his assets prejudgment includes some form of equitable component to the requested relief, recent decisions have distinguished Grupo Mexicano and been willing to issue the injunction on the basis that Grupo Mexicano only concerned a claim solely for money damages, a strictly legal claim. See, e.g., (where minority shareholder brought action seeking to enjoin sale of substantially all of a company's assets, Ninth Circuit distinguished Grupo Mexicano by finding that the requested injunction did "not completely prohibit appellants from taking any action with regard to their assets" and "merely restrains appellants from either completing the 1998 agreement or liquidating [the company]."); United States, Rahman v. Oncology Assoc. P.C., ${ }^{45}$ (finding that where a plaintiff included a request for imposition of a constructive trust with its fraud claim, Grupo Mexicano was not implicated because "the bill contains allegations which, if proved, entitle petitioners to some equitable relief.");

\section{(ii) The Practice of Mareva in Canada}

Like the system obtaining in UK there is the practice of Mareva being issued by the Courts in Canada too. In Aetna

${ }^{45} 198$ F. 3d 4889, 497. 98 (4thCir. 1999) 
Financial Services Ltd. v. Feigelman, the Supreme Court of Canada confirmed the adoption of the remedy of a Mareva injunction under Canadian law:

The gist of the Mareva action is the right to freeze eligible assets when

Found within the jurisdiction, wherever the defendant may resident, providing

of course, there is a cause between the plaintiff and the defendant which is

justiciable. .... However, unless there is a genuine risk of disappearanace of

assets either inside or outside the jurisdiction, the injunction will not issue. ${ }^{46}$

To obtain a Mareva injunction the claimant must demonstrate to the court that there is a strong prima facie case of fraud. That $\mathrm{s}$, where the evidence is merely suggestive of wrongdoing, a Mareva injunction will not be granted. In addition the claimant has to :

${ }^{46} 1985$ CarAwell Man 19, 1985, Carawell Man 379 (1985) 1 SCR 2 (SACC) Aetna) 
1. make full and frank disclosure of all material matters;

2. demonstrate to the court that it has a strong prima facie case against the defendant and provide $r$ of the claim, the grounds of it and the amount thereof, and fairly state the points made against it by the defendant;

3. show some grounds for believing the defendant has assets within the court's jurisdiction;

4. show some grounds for believing there is a risk of the assets being removed or dissipated before judgment is satisfied; and

5. give an undertaking as to damages.

\section{(iii) The Practice of Mareva Injunction in Australia}

The practice in the Federal Court of Australia is outlined in a Practice Note $^{47}$ the freezing orders issued by the Court in

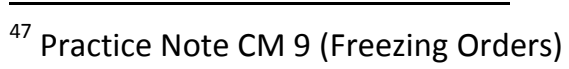


Australia are also known as 'Mareva Orders' or 'Asset Preservation Orders. The Practice Note supplements Division 7.4 of the Federal Court Rules 2011 relating to freezing orders ( also known as 'Mareva Orders' after Mareva Compania Naviera SA v. International Bulkcarriers SA or 'asset preservation orders.

This Practice Note addresses (among other things) the Court's usual practice relating to the making of a freezing order and the usual terms of such an order. While a standard practice has benefits, this Practice Note and the example form of order annexed to it do not, and cannot, limit the judicial discretion to make such order as is appropriate in the circumstances of the particular case. ${ }^{48}$

According to this Note, the purpose of a freezing order is to prevent frustration or abuse of the process of the court, not to provide security in respect of a judgment or order. A freezing order in Australia is viewed as an extraordinary interim remedy because it can restrict the right to deal with assets even before judgment and is commonly granted without notice.

\footnotetext{
${ }^{48}$ Rule 2 of the Practice Note.
} 
The respondent is often the person said to be liable on a substantive cause of action of the applicant. However, the respondent may also be a third party, in the sense of a person who has possession, custody or control or even ownership of assets which he or she may be obliged ultimately to disgorge to help satisfy a judgment against another person.

The Practice Note addresses the minimum requirements that must ordinarily be satisfied on an application for a freezing order against such a third party before the discretion is enlivened. The third party will not necessarily be a party to the substantive proceedings but will be a respondent to the application for the freezing or ancillary order. Where a freezing order against a third party seeks only to freeze the assets of another person in the third party's possession, custody or control (but not ownership) the example form will require adaptation. ${ }^{49}$

(iv) The practice of Mareva Injunction in Hong Kong

\footnotetext{
${ }^{49}$ Rule 7.35 (5) of the Practice Note.
} 
In view of very vast business transactions among the people of Hong Kong questions arise among the members of legal fraternity whether there is the system of freezing bank accounts or seizing assets in Hong Kong in aid of foreign proceedings. Until recently the position was that if the substantive proceedings or the defendant itself had no connection to Hong Kong, it was unlikely that the Hong Kong Courts would exercise jurisdiction to grant a pre-judgment injunction/freezing order in aid of foreign proceedings. That position has now changed, however and changed quite radically. ${ }^{50}$

The issue of Mareva Injunction by the Courts in Hong Kong is a subject figuring in the broader area of Civil Justice Reform (CJR). The issue as to whether the Hong Kong Courts should have power to grant interim relief-including an interim injunction in aid of foreign proceedings-- was reviewed prior to the enactment of the CJR. The general view in the legal community was in support of such reform.

\footnotetext{
${ }^{50}$ Freezing Orders and injunctions under the Hong Kong Civil Justice Reform, Blankrome Publications, July 2009 (No.3)
} 
Nowadays, monies can be transferred electronically and goods can move across borders very quickly. The Hong Kong 'view' now appears to be that it is a commercial necessity for Courts of different jurisdictions to cooperate and assist each other to prevent foreign defendants form defeating a judgment by transferring or moving assets of the jurisdiction. ${ }^{51}$

Hong Kong is undergoing a process of Civil Justice Reform. This came into effect on April 2, 2009. The Hong Kong Courts now have clear statutory power to grant interim injunctions against a foreign defendant who has assets located within Hong Kong, regardless of whether or not the substantive dispute has a nexus with Hong Kong or the defendant is domiciled or present. A claimant can therefore now apply to the Hong Kong Court for a 'Mareva'/freezing order style injunction to restrain a defendant from dealing with or disposing wholly of its assets, whether they are monies on account, goods, or real properties etc. Any third party that holds, possesses or has control of such assets are also subject o the injunction proceedings.

In order to accomplish this, amendments were made to the High Court Ordinance and Arbitration Ordinance so that the Hong

\footnotetext{
${ }^{51}$ Newsletter of the Blankrome LLP July 2009 (No.3; http: www.BlankRomeMaritime.com retrieved on 24.3.2018
} 
Kong Courts now have the power to grant interim relief in the absence of substantive proceedings--- including an interim injunction-- against the defendant, restraining it from dealing with its assets within the Hong Kong High Court jurisdiction. This effectively reverses the House of Lords' decision in Siskina in which Lord Diplock stated that an interim injunction was not a cause of action by itself and could not stand on its own, but was ancillary and incidental to a pre-existing cause of action.

\section{(v) The Practice of Mareva Injunction in Nigeria :}

Section 6(6) of the Constitution of the Federal Republic of Nigeria, 1999 contains the provision as a root of the court's power to exercise statutory, equitable and inherent jurisdiction. The court's power to grant mandamus, injunction or appoint a receiver is usually donated by statute establishing the relevant court pursuant to the 1999 Constitution and amplified by the relevant court rules. However, in terms of case law in Nigeria, recognition of Mareva Injunction may be first traced to the Supreme Court case of Satiminu v. Ocean Steamship (Nig.) Ltd. ${ }^{52}$ in 1992 where the Supreme Court acknowledged as a preventive measure the power of the court to grant anticipatory and

52 (1992) 5 NWLR (pt 239) 1 
preservative ex parte injunction to a plaintiff with a good prima facie case against a "mischievous" defendant planning to remove assets outside the jurisdiction of the court before judgment.

Mareva Injunction has not only gained a pride of place in commercial dispute in Nigeria but also enjoys statutory patronage in the country's right against corruption, terrorism, and money laundering in addition to special case management rules developed by the courts to fast track prosecution of these cases. ${ }^{53}$ Accordingly, sections 26, 28 and 34 of the Economic and Financial Crimes Commission (EFCC) Act 2004, Sections 12 and 16 of the Terrorism (Prevention) Act 2011 inter alia make provision for law enforcement and investigative agencies to administratively but temporarily freeze the accounts of a person suspected of having committed economic and financial crimes, attach funds and properties allegedly associated with proceeds of crime alleged to have been committed by such persons by a freezing (Mareva) Injunction issued by the Court pending determination of the criminal charge. ${ }^{54}$

\footnotetext{
${ }^{53}$ Federal High Court Practice Direction 2013 dated 30 ${ }^{\text {th }}$ April 2013/

${ }^{54}$ Sections 49and 50 of the Asset Management Corporation of Nigeria Act 2010.
} 


\section{VIII: Conclusion}

After making a detailed survey of the literature on the Remedy of Mareva Injunction in English Law it may be concluded that the Courts in England have done a wonderful work through their activism. The initiative taken by Lord Denning in the Court of Appeal by creating Mareva Injunction has made a history in the matter of protecting the interests of the creditors in commercial transactions, which kind of protection has been afforded by the courts in other areas as well. In other words, the work of the Court of Appeal was a measure, on the one hand, to protect the creditors in the commercial world and a work, on the other hand, to protect the majesty of the English Law as well. The history of English law analysed by the author in this article confirms that the English Legal System has grown and developed in the lap of the Judiciary, which fact is confirmed by the work of Lord Denning in the Court of Appeal. By enacting necessary legislation in the form of the Supreme Court Act the British Parliament has endorsed the contribution of the Courts and maintained the basic truth of the English Legal System that there are three sources of English Law pursued by three different agencies since ancient days, and the same trio has something to 
do for the good of the Legal System. The idea of Mareva has been at work in other jurisdictions too, from which we have to accept the fact that the work of Lord Denning in the creation of Mareva was a significant contribution of the learned Judge to the commercial world on the one hand and the legal system of the country on the other hand.

\section{B I B L I O G R A P H Y}

1. The Oxford English Dictionary (1933).

2. Collins English Dictionary (1989)

3. Law Dictionary $\left(10^{\text {th }}\right.$ ed) E.R. Hardy Ivamy, Butterworths.

4. Pollock and Maitland, 'History of English Law'.

5. Penny Darbyshire on the English English Legal system

6. Halsbury's Laws of England: Being a complete statement of the whole law of England,

published 1907-1917.

7. Theories and principles underlying the development of the Common Law, Mark

Learning, UNSW Law Journal, vol. 36,

8. Glanville : Laws and customs of the Realm of Englad. 
9. R. C. Van Caenegem, Royal Writs in England from the Conquest to Glanville, Studies in

the early History of the Common Law (Selden society, 77, 1959)

10. M. Haggar, 'The earliest Norman writs revisited', Historical Research, 82 (2009)

11. J. Hudson, The Fromation of the English Common Law and Society in England from

the Conquest to Magna Carta (London, 1996)

12. R. Sharpe, 'The Use of Writs in the eleventh century, Anglo Saxon England, 32 (2003)

13. Harmer, Anglo Saxon Writs.

14. A. J. Robertson, the Laws of the Kings of England from Edmund to Henry I (Cambridge, 1925).

15. W. Stubbs, Select Charters and other Illustrations of English Constitutional History. Rev.

H. W. C. Davis, (9 ${ }^{\text {th }}$ ed. Oxford, 1913)

16. Douglas and G. W. Greenaway, English Historical Documents, 2, (London, 1953). 
17. Snell, Edmund Henry Turner, Megarry R. E. Baker, P. V. (1960) Snell's principles of Equity, ( $25^{\text {th }}$ ed.) London,

18. Slapper and Kelly, English legal system Routledge, 2016

19. Coke and Blackstone, History of English Law.

20. A Denning, 'The Due Process of Law (1980)

21. R. J. Walker, Principles of Scottish Private Law, (1975)

22. Rose, The Mareva Injunction, attachment in personam, Part I (1981) Lloyd's Mar. \&

Coim. L. Q.

23. Wood, Protective Measures for Recovering Debts in England and Wales, 2 International

. journal of comparative constitutional law.

24. Collis Lawrence (1989) The Territorial Reach of Mareva Injunction, Law Quarterly

Review, ISSN 0023

25. Harris Bor (2014) "Freezing Orders in support of arbitration proceedings, Journal of

International Banking and Financial Law, Butterworths, 26. Aird, Richard (2010) 'The best kept secret in commercial litigation,, The Commercial 


\section{Litigation Journal ISSN 1747}

27. May Lee, (1982) Prejudgment attachment in England, Loyola of Los Angeles

International and Comparative Law Review, Loyola.

28. Shantanu Majumdar, Christopher Buckley, 'Freezing Injunctions, 